\title{
Some Electrochemical and Physical Properties on Molten $\mathrm{BeCl}_{2}$ *
}

\author{
Kenichi OHMAE*, Tadashi KurodA** \\ *Nuclear Engineering Department, Massachusetts Institute of \\ Technology, Cambridge, Mass. \\ **Research Laboratory of Nuclear Reactors, Tokyo Institute of \\ Technology, O-okay ama, Meguro-ku, Tokyo
}

Received March 31, 1967

\begin{abstract}
Physicochemical properties of the granular $\mathrm{BeCl}_{2}$ crystals have been investigated for the samples obtained by the fractional vacuum condensation. The melting point and boiling point were $392^{\circ}$ and $474^{\circ} \mathrm{C}$, respectively.

The crystal was proved to be far less deliquencent than the commercial $\mathrm{BeCl}_{2}$. When the crystal was let standing for $1100 \mathrm{hrs}$ in air, stable $\mathrm{BeCl}_{2} \cdot 10 \mathrm{H}_{2} \mathrm{O}$ was obtained.

Polarogram of $\mathrm{BeCl}_{2}$ in CLCl-KCl-NaCl eutectic mixtures gave the half-wave potential of $-1.95 \mathrm{~V}$ at $460^{\circ} \mathrm{C}$ which corresponds to the redox couple of $\mathrm{Be} / \mathrm{Be}^{++}$.

Electric conductivity of the pure molten $\mathrm{BeCl}_{2}$ increased linearly with the raise of temperature in the region between 412 and $473^{\circ} \mathrm{C}$.

Specific conductivity at and below the melting point was found to be very small, indicating the strong co-valency of the crystal $\mathrm{BeCl}_{2}$.

The activation energy for the electric conduction in the molten $\mathrm{BeCl}_{2}$ changed sensitively with the change of temperature.

The analysis of the date indicated that the electric conduction in pure molten $\mathrm{BeCl}_{2}$ is purely ionic.
\end{abstract}

\section{Introduction}

In view of obtaining pure beryllium by the electrolysis in fused salt, we have prepared pure beryllium chloride by the fractional condensation. A new crystal thus obtained as granular form was found to be stable against the moisture as compared with the ordinary sample of acicular form 1 ).

In the present investigation the various physicochemical properties of the granular $\mathrm{BeCl}_{2}$ have been measured in an attempt to provide new data and mechanisms of ionic conductivity.

\section{Experiment 1}

\subsection{Melting and Boiling Measurements}

Pure crystal of $\mathrm{BeCl}_{2}$ prepared by the fractional vacuum condensation was used. The measurements were performed in the dried and purified Agron atmosphere. The temperature was measured by the Chromel-Alumel thermocouple which was calibrated with respect to the melting points of $\mathrm{Sn}\left(231.85^{\circ} \mathrm{C}\right), \mathrm{Pb}\left(327.5^{\circ} \mathrm{C}\right)$, $\mathrm{Zn}\left(419.4^{\circ} \mathrm{C}\right)$ and $\mathrm{Sb}\left(630.5^{\circ} \mathrm{C}\right)$.

\subsection{Deliquescence}

About $10 \mathrm{~g}$ of samples were placed in the atmosphere of $58 \%$ relative humidity at $14.5^{\circ} \mathrm{C}$. The weight of the sample was measured every definite period.

\subsection{Polarogram}

Although many problems have remained unresolved in the polarography of fused salt, the solid micro-electrode developed in our laboratory shows satisfactory reproducibility. Cell used for obtaining polarogram is illustrated in Fig. 1. 


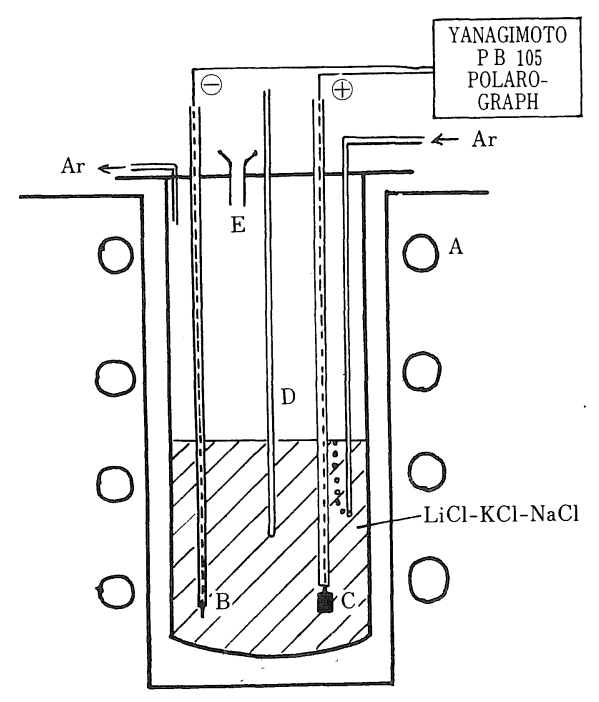
A : Electric furnace
B : Micro-electrode
C : Reference electrode
D : Thermocouple
$\mathrm{E}: \mathrm{BeCl}_{2}$ entrance

Fig. 1 Apparatus for fused salt polarography

The micro-electrode of Mo used in this experiment, however, had a surface area of only $0.80 \mathrm{~mm}^{2}$ and it may well be called a pointelectrode. Before each run, the electrodes were washed with dilute $\mathrm{HCl}$, and Argon gas was bubbled for about 30 minutes to get rid of $\mathrm{O}_{2}$ in the melt.

Universal Bridge (BV-Z-13B, $1000 \mathrm{c} / \mathrm{s}$ ) manufactured by the Yokogawa Electric Works was used to measure the resistance of the conduction celi. Cell constant was determined by three standard solutions as reported by Bremner2), the resistance being measured at 0.1 and $18^{\circ} \mathrm{C}$ for each solution. The cell constant was found to be 17.29 , which is comparatively small indicating that the size of capillary is too big.

$\mathrm{BeCl}_{2}$ is highly viscous and this cause the difficulty of balancing the surface levels at both sides of the cell, when narrow capillary was used.

\section{Results and Discussion}

\section{1.}

Obtained Results are Shown in Table 1. Sample B agrees with the result reported by
Table 1 Melting and Boiling Point of Pure $\mathrm{BeCl}$

\begin{tabular}{cl|c|c}
\hline \hline & $\operatorname{mp}\left({ }^{\circ} \mathrm{C}\right)$ & b.p. $\left({ }^{\circ} \mathrm{C}\right)$ \\
\hline$A \quad \begin{array}{l}\text { From Run 17 in Part I (Table 2) } \\
\text { (granular, bluish) }\end{array}$ & 392 & 474 \\
\hline B $\quad \begin{array}{l}\text { From Run 1 in Part I (Table 2) } \\
\text { (acicular, white) }\end{array}$ & 400 & 477 \\
\hline C $\quad \begin{array}{l}\text { Crude (Nippon Gaishi Co. Ltd, } \\
95 \% \text { up) }\end{array}$ & 383 & 491 \\
\hline
\end{tabular}

Furby and Wilkinson( ${ }^{3}$ (i.e. melting point $399 \pm 1^{\circ} \mathrm{C}$, boiling point $482.5 \pm 1^{\circ} \mathrm{C}$ ).

Sample A gives the lowest values ever reported. But these are supported to be meaningful by the electric conductivity measurement (See. IV) and also by the visual observations.

Low melting point and high boiling point of sample $\mathrm{C}$ are probably due to the impurities included.

\subsection{Deliquescence}

The strong deliquescence of acicular $\mathrm{BeCl}_{2}$ causes many troubles in industrial handling. The large granular crystals obtained in the preceding study have less surface area per unit volume than that of the regular needle crystals, hence, higher in bulk density.

Fig. 2 shows the rate of initial weight change of $\mathrm{BeCl}_{2}$ of three different origins.

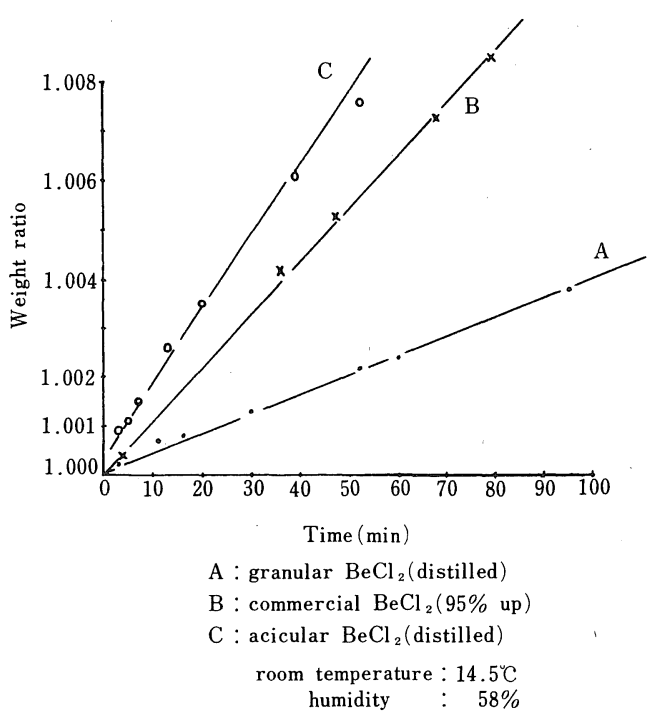

Fig. 2 Initial weight change of $\mathrm{BeCl}_{2}$ 
In the initial stage, exposed to the moisture in the air, the commercial $\mathrm{BeCl}_{2}$ deliquesces twice as quickly as the granular $\mathrm{BeCl}_{2}$. Whereas, the acicular $\mathrm{BeCl}_{2}$ increases in weight more rapidly than that of the commercial one, indicating the difficulty of obtaining anhydrous $\mathrm{BeCl}_{2}$ in such a form.

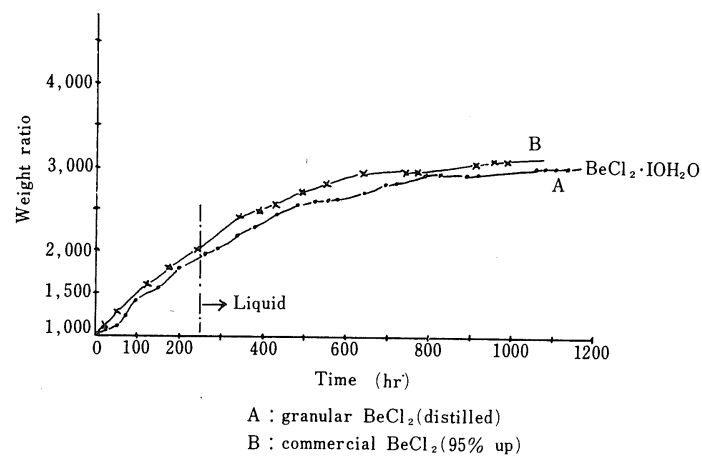

Fig. 3 Long term weight change of $\mathrm{BeCl}_{2}$

Fig. 3 shows the long term deliquescent properties of $\mathrm{BeCl}_{2}$. Both samples reach to a certain saturated value after some 1100 hours exposure to the air. Although the plateau corresponds to $\mathrm{BeCl}_{2} \cdot 10 \mathrm{H}_{2} \mathrm{O}$, it does not mean that such as component actually exists.

Crystal $\mathrm{BeCl}_{2}$ dissolves itself into its own crystalline water after about 250 hours in the air to form $\mathrm{BeCl}_{2} .5 \mathrm{H}_{2} \mathrm{O}$.

In the measurement of weight increase, no correction was made for the evaporation loss of $\mathrm{BeCl}_{2}$, because the vapor pressure of $\mathrm{BeCl}_{2}$ at room temperature is less than $10 \mathrm{mmHg}^{4}$ ) and it is expected to be negligibly small.

It should be noted that the granular $\mathrm{BeCl}_{2}$ obtained in the preceding investigation.

The micro-electrode was designed so as to avoid the influence of the following disproportionation reaction reported by Smirnov et al. 5),6)

$$
\mathrm{Be}+\mathrm{Be}^{++}=2 \mathrm{Be}^{+}
$$

As shown in Fig. 1, a large platinum reference electrode, with the surface area of $492 \mathrm{~mm}^{2}$ was used in spite of its reactivity in molten chlorides.

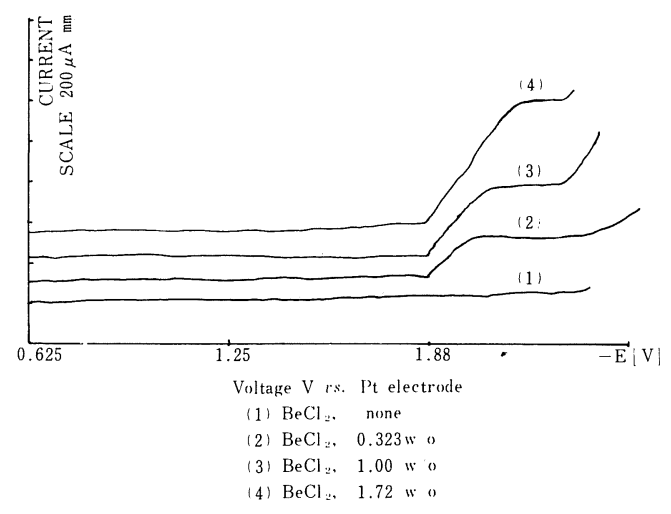

Fig. 4 Polarogram of $\mathrm{BeCl}_{2}$ in LiCl$\mathrm{KCl}-\mathrm{NaCl}$ (Mo Point electrode)

Fig. 4 shows a typical program of $\mathrm{BeCl}_{2}$ in the alkali chlorides bath. To avoid the drawing over the same line, zero point of successive run is shifted above arbitrarily in Fig. 4 and Fig. 5.

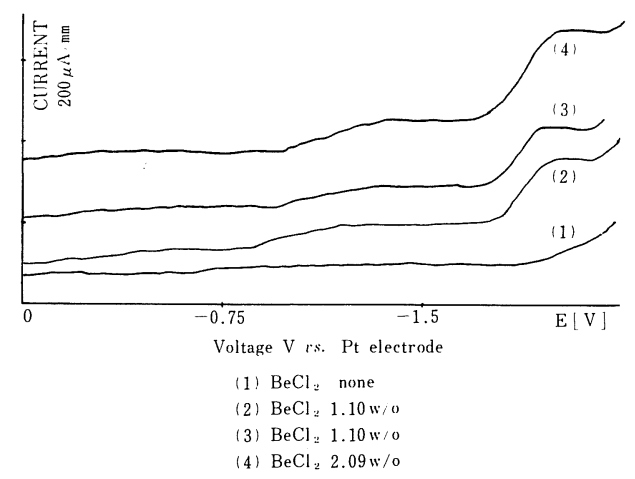

Fig. 5 Polarogram of $\mathrm{BeCl}_{2}$ in LiCl$\mathrm{KCl}-\mathrm{NaCl}$ (Mo micro-electrode)

Summary of the results are listed in Table 2.

Table 2 Half-wave Potential and the Wave-height of $\mathrm{BeCl}_{2}$ in $\mathrm{LiCl}$ $\mathrm{KCl}-\mathrm{NaCl}$ Eutectic Mixture at $460^{\circ} \mathrm{C}$

\begin{tabular}{c|c|c}
\hline \hline $\mathrm{BeCl}_{2}$ in $\mathrm{wt} \%$ & $-\mathrm{E}_{1 / 2}(\mathrm{~V})$ & Wave-height (Amp.) \\
\hline 0.323 & 1.91 & $7.3 \times 10^{-4}$ \\
1.00 & 1.95 & $15.3 \times 10^{-4}$ \\
1.72 & 1.99 & $28.0 \times 10^{-4}$ \\
\hline
\end{tabular}

scanning speed: $\quad 0.167 \mathrm{~V} / \mathrm{min}$ surface area ratio: $\mathrm{Mo}($ cathode): $\mathrm{Pt}$ (anode) $=0.80: 492\left(\mathrm{~mm}^{2}\right)$ 
The theoretical calculation of the standard potential of the reaction

$$
\mathrm{Be}(S)+\mathrm{Cl}_{2}(g)=\mathrm{BeCl}_{2}(l)
$$

can be made using the following thermochemical data:

$$
\begin{aligned}
& S^{298}{ }_{\mathrm{BeCl}_{2}}=21.5 \pm 2.5 \text { e.u. }{ }^{7} \text { ) } \\
& S^{298}{ }_{\mathrm{Be}}=2.28 \pm 0.02 \text { e.u. }{ }^{8)} \\
& \left.S^{298} \mathrm{Cl}_{2}=53.5 \pm 0.02 \text { e.u. }{ }^{8}\right) \\
& \begin{aligned}
C p_{1 \mathrm{BeCl}_{2}}=18.7+0.68 & \times 10^{-3} \mathrm{~T}+0.30 \\
\times & \left.10^{5} / T^{2} 9\right)
\end{aligned} \\
& C p_{1 \mathrm{Be}}=4.54+2.12 \times 10^{-3} \mathrm{~T}-0.82 \\
& \left.\times 10^{5} / T^{210}\right) \\
& C p_{1 \mathrm{Cl}_{2}}=8.82+0.06 \times 10^{-3} \mathrm{~T}-0.68 \\
& \times 10^{5} / T^{211} \\
& \Delta H_{\mathrm{BeCl}_{2 \beta \rightarrow a}}=1.490 \mathrm{Kcal} / \mathrm{mol}^{12} \text { ) } \\
& \Delta H_{\mathrm{BeCl}_{2} a \text {-melt }}=2.07 \mathrm{Kcal} / \mathrm{mol}^{12} \text { ) } \\
& \Delta H^{298}=-118.03 \pm 0.56 \mathrm{Kcal} / \mathrm{mol}^{13} \text { ) } \\
& \Delta G \simeq-n F E
\end{aligned}
$$

From these data, we get

$$
E=-4.046 / \mathrm{n}(\mathrm{V}) \text { at } 733^{\circ} \mathrm{K}=-2.023 \mathrm{~V}
$$$$
\text { (for } \mathrm{n}=2 \text { ) }
$$

When the concentration of $\mathrm{BeCl}_{2}$ is dilute enough and the diffusion coefficient $D_{0}$ of the solute in oxidation state and $D_{R}$ in reduction state are nearly equal to each other, $E_{1 / 2}$ can be taken as $E_{o}$, if no other reaction occurs at the electrodes.

Although the anodic reaction on $\mathrm{Pt}$ is complicated and not certain, the theoretical calculation based on the $\mathrm{Cl}^{-} / \mathrm{Cl}_{2}$ reaction closely agrees with the experimental results, indicating that such is the case of above reaction. According to Delimarskii 14 ), polarization potential of large reference Pt electrode is about $+0.1 \mathrm{~V}$ or in most cases negligible. If we use the value $0.1 \mathrm{~V}$ for the polarization, we can put $E_{1 / 2} \simeq E_{0} \simeq-1.99-(+$ $0.1)=-2.09 \mathrm{~V}$, which is remarkably close to the theoretical calculation. Thus the wave observed at $-1.99 \mathrm{~V}$ is concluded to correspond to $\mathrm{Be} / \mathrm{Be}^{++}$ $(n=2)$.

No other wave was observed with the point electrode. But, when Be metal existed in the melt (i.e., either by inserting a $\mathrm{Be}$ rod in the bath or by once imposing a voltage above that of the decomposition of $\mathrm{BeCl}_{2}$ between the micro-electrode (not the point-electrode) and the Pt-reference), a new wave as seen in Fig. 5 was found at $-1.1 \mathrm{~V}$. With the assumption that the rate determining process is the diffusion of ions toward the electrodes, we carry out I1kovic plot of the new wave.

Results shows that $n$ should be half of that corresponding to $\mathrm{Be} / \mathrm{Be}^{++}$, namely, $n=1$.

This can either be $\mathrm{Be}^{+} / \mathrm{Be}^{++}$or $\mathrm{Be} / \mathrm{Be}^{+}$, but since the wave was not observed when Be metal was absent in the melt, it must be attributed to the latter, which supports the hypothesis presented by Smirnov et $\mathrm{al}^{5}$ ),6).

\subsection{Electric Conductivity}

The electric conductivity of $\mathrm{BeCl}_{2}$ has been reported by many authors15),16),17), but most of them measured the conductivity of $\mathrm{BeCl}_{2}$ in alkali chlorides and extraporated it to $\mathrm{BeCl}_{2}$. At one atm, liquid $\mathrm{BeCl}_{2}$ is stable only in the temperature range between 392 and $474^{\circ} \mathrm{C}$. The vapor pressure being very high at elevated temperatures, many investigators have pointed out that it is difficult to keep the liquid $\mathrm{BeCl}_{2}$ stable for a prolonged period. The granular $\mathrm{BeCl}_{2}$ obtained by the fractional vacuum condensation, however,

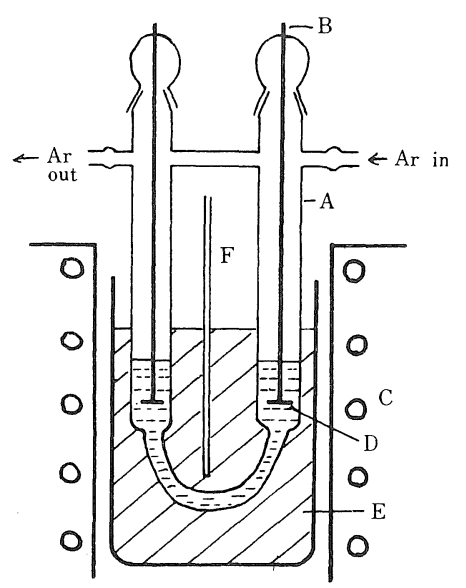

$$
\begin{aligned}
& \text { A : quartz cell } \\
& \mathrm{B}: \mathrm{Pt} \text { wire } \\
& \mathrm{C}: \text { electric furnace } \\
& \mathrm{D}: \mathrm{Pt} \text { disk } \\
& \mathrm{E}: \mathrm{LiCl}-\mathrm{KCl}-\mathrm{NaCl} \text { bath } \\
& \mathrm{F}: \text { thermocouple }
\end{aligned}
$$

Fig. 6 Apparatus for electric conductivity measurement 
melts to form yellowish, transparent liquid which stays in the conduction cell (Fig. 6) for a few hours under $\mathrm{Ar}$ gas atmosphere. This enables ones to measure electric conductivity of pure liquid $\mathrm{BeCl}_{2}$. The conduction cell and apparatus used for this experiment is shown in Fig. 6.

Specific conductivity $\mathrm{K}$ and molar conductivity $\mu$ of $\mathrm{BeCl}_{2}$ observed are listed in Table 3 .

Table 3 Conductivity of Pure $\mathrm{BeCl}_{2}$

\begin{tabular}{l|l|l}
\hline \multicolumn{1}{c|}{$\mathrm{t}^{\circ}(\mathrm{C})$} & $\mathrm{K}\left(\Omega^{-1} \mathrm{~cm}^{-1}\right)$ & $\mu\left(\Omega^{-1} \mathrm{~cm}^{2} / \mathrm{mol}.\right)$ \\
\hline 482 & $3.7694 \times 10^{-3}$ & $2.078 \times 10^{-1}$ \\
475 (b.p.) & 4.0518 & 2.224 \\
469 & 4.0188 & 2.197 \\
463 & 3.6847 & 2.008 \\
459 & 3.3402 & 1.815 \\
452 & 2.8141 & 1.523 \\
446 & 2.4218 & 1.305 \\
442 & 2.0742 & 1.115 \\
436 & 1.7910 & $9.594 \times 10^{-2}$ \\
427 & 1.2860 & 6.852 \\
422 & $8.7012 \times 10^{-4}$ & 4.621 \\
419 & 6.9968 & 3.708 \\
415 & 4.4028 & 2.329 \\
412 & 2.0711 & 1.093 \\
407 & $7.7860 \times 10^{-5}$ & $4.099 \times 10^{-3}$ \\
404 & 2.180 & 1.146 \\
402 & $6.54 \times 10^{-6}$ & $3.43 \times 10^{-4}$ \\
399 & 1.87 & $9.79 \times 10^{-5}$ \\
395 & $3.11 \times 10^{-7}$ & 1.63 \\
394 & 1.56 & $8.14 \times 10^{-6}$ \\
393 (m.p.) & $\sim 0$ & $\sim 0$ \\
\hline
\end{tabular}

Fig. 7 shows the observed relation between $\mu$ and $t^{\circ} \mathrm{C}$, from which the following equation is derived:

$$
\begin{aligned}
& \mu=0.1490+0.003663(\mathrm{t}-451) \\
& \text { or } \Lambda=0.0745+0.007326(\mathrm{t}-451)
\end{aligned}
$$
$\left(412 \sim 470^{\circ} \mathrm{C}\right)(1)$

This shows a surprising agreement with the result reported by $\mathrm{W}$. Biltz et al.,15)viz.

$$
\Lambda=0.087+0.0073(\mathrm{t}-451)
$$

But careful investigation of their results prove that (1) and (2) meet well only around $451^{\circ} \mathrm{C}$. Drossbach gave the specific conductivity of $\mathrm{BeCl}_{2}$ to be $0.0032+0.26 \times 10^{-3}(\mathrm{t}-451)(3)$

This also agree with our results around $451^{\circ} \mathrm{C}$. $\mathrm{He}$ reported the equivalent conductivity at the melting point $\left(440^{\circ} \mathrm{C}\right)$.

$$
\Lambda \text { (m.p.) }=0.088
$$

Our observation shows that $\Lambda m . p$. is nearly equal to zero $\left(m \cdot p .=392^{\circ} \mathrm{C}\right)$ or, at least, smaller

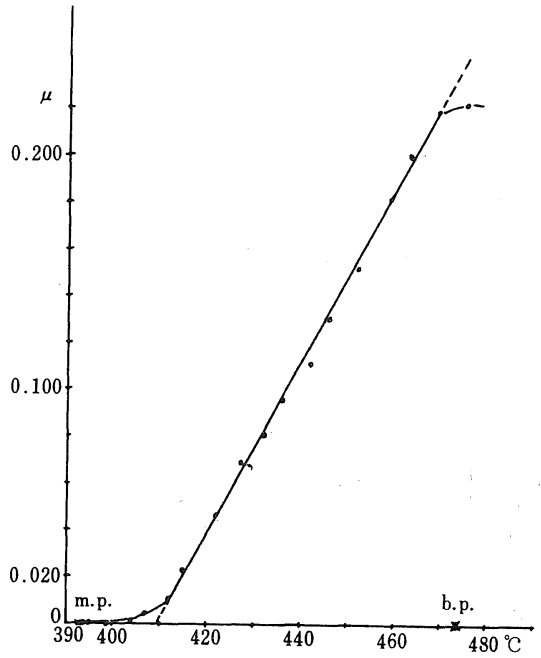

Fig. $7 \mu$ vs. $t^{\circ} \mathrm{C}$

than $1 \times 10^{-6} \mathrm{mho} \cdot \mathrm{cm} /$ equi.

It is clearly seen in Fig. 7 that molar conductivity approaches to maximum at $470^{\circ} \mathrm{C}$.

Melting point and boiling point measurement

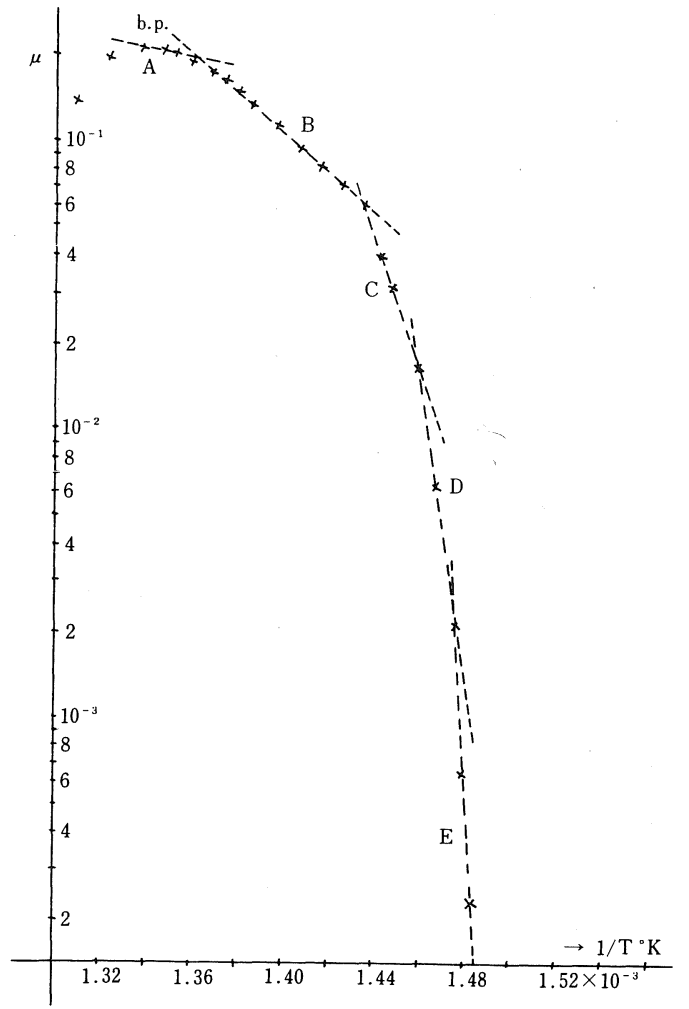

Fig. $8 \quad \log \mu$ vs. $1 / \mathrm{T}^{\circ} \mathrm{K}$ (cf. Table 4 ) 
Table 4 Activation Energy for Electric Conduction in Molten $\mathrm{BeCl}_{2}$

\begin{tabular}{l|c}
\hline \hline Temperature Range $\left({ }^{\circ} \mathrm{C}\right)$ & $\begin{array}{c}\text { Activation Energy } \\
\text { (Kcal/mol) }\end{array}$ \\
\hline A. 474 (b.p. $) \sim 452$ & 9.31 \\
B. $452 \sim 424$ & 32.32 \\
C. $424 \sim 413$ & 88.13 \\
D. $413 \sim 405$ & 241.5 \\
E. $405 \sim 392$ (m.p.) & 493.7 \\
\hline
\end{tabular}

in Sec. I tells us that $\mathrm{BeCl}_{2}$ melts at $392^{\circ} \mathrm{C}$ and boils at $474^{\circ} \mathrm{C}$. Therefore the conductivity irregularity must correspond to the structural change which accompanies the abrupt change in chemical bonds.

From Fig. $8\left(\log \mu\right.$ vs. $\left.1 / \mathrm{T}^{\circ} \mathrm{K}\right)$, the activation energy $E \mu$ for electric conduction of molten $\mathrm{BeCl}_{2}$ is calculated as listed Table 4.

It is clear that $E \mu$ changes with temperatures; linearity is held only for a certain temperature range, showing the rapid change of the mechanism of electric conduction or of the structure of the melt.

Solid state $\mathrm{BeCl}_{2}$ forms a strong covalent network between $\mathrm{Be}$ and $\mathrm{Cl}^{18}$ ). Whereas the vapor structure is not certain, but recent investigations $\mathrm{s}^{4}, 19$ ) are in favor of the existence of monomer prevailing over dimer.

No interpretation of the structure of liquid $\mathrm{BeCl}_{2}$ has ever been proposed. The strong network will still exist even after melting. The electric conduction at this stage will be very difficult, for an ion must migrate by cutting through this network. Therefore the activation energy for the ionic migration will be as large as the lattice energy (i.e. $\sim 200 \mathrm{Kcal} / \mathrm{mol}$ ). Because of the strong covalency, few ionization will take place even through the electric field is applied, resulting in the low specific conductivity of the melt and high activation energy near melting temperature. As the temperature is raised, the number of activated $\mathrm{Be}^{++}$will increase and the network will also be loosened. This will make easy to move ion with smaller activation energy and the linear increase would occur in the electric conductivity. As this range, the observed conductivity will be the sum of cationic and anionic conductivity as mentioned by Eucken. Eucken.

$$
\mu=A_{1} \exp (-E c / R T)+A_{2} \exp \left(-E_{A} / R T\right)
$$

where, $E_{c}$ : activation energy for the cationic migration.

$E_{A}:$ activation energy for the anionic migration

$$
\gamma \mathrm{Be}^{++}: \gamma \mathrm{Cl}^{-}=0.33 \AA: 1.81 \AA
$$

If $E_{\mathrm{c}}$ and $E_{A}$ are the function of temperature, the overall conductivity will not be expressed by a simple Arrhenius equation, but (4) can be applied to it. Therefore the relation, $\log \mu$ vs. $1 / \mathrm{T}^{\circ} \mathrm{K}$ will not be a simple line, but will change gradually with temperature. This seems to be the case of molten $\mathrm{BeCl}_{2}$ between 412 and $474^{\circ} \mathrm{C}$. Near the boiling point, no network will exist any more because of the strong thermal agitation, hence the activation energy for the conduction will be used to overcome such agitation. But even at this stage, the covalency of $\mathrm{Be}-\mathrm{Cl}$ bond will remain and not all of the molecules are ionized, this may be the main reason why $\mathrm{BeCl}_{2}$ has such a small conductivity in comparison with other alkali and alkaline-earth chlorides even at its boiling point.

Thus the so far proposed mechanisms for electric conduction ${ }^{21}$ ) or electronic conduction $^{22), 23)}$ can not simply be applied to molten $\mathrm{BeCl}_{2}$.

Exchange of position between the ions and the sub-lattice requires larger activation energy for ionic conduction. Judging from the magnitude of $E \mu$ of $\mathrm{BeCl}_{2}$, we consider that such exchange must be the main mechanism of electric conduction near the melting point. But at present, no quantitative interpretation of the activation energy change is possible, because the structure of fused salt is not well known to enable such calculations.

\section{Conclusion}

Using the pure $\mathrm{BeCl}_{2}$ crystals obtained by the fractional vacuum condensation, the following results were obtained:

(1) m.p. $=392^{\circ} \mathrm{C}$, b.p. $=474^{\circ} \mathrm{C}$.

(2) Present crystal is superior in deliquency to regular acicular $\mathrm{BeCl}_{2}$.

(3) $E^{1 / 2}=-1.99 \mathrm{~V}$ for $\mathrm{Be} / \mathrm{Be}^{++}$at $460^{\circ} \mathrm{C}$ was obtained by the molten salt polarography using a point Mo electrode. 
(4) $\mu_{\text {m.p. }}=0 \quad \mu_{\text {b.p. }}=0.224\left[\mathrm{mho} \mathrm{cm}^{2} / \mathrm{mol}\right]$ $\mu=0.1490+0.003663(\mathrm{t}-451)\left(412 \sim 470^{\circ} \mathrm{C}\right)$

(5) The activation energy for electric conduction of molten $\mathrm{BeCl}_{2}$ is the function of temperature, and the mechanism of conduction, which is purely ionic, changes with the change in temperature.

\section{Literature:}

1) T. Kuroda, K. Ohmae, This Journal 36, No. 3 (1968).

2) R. W. Bremner, T. G. Thompson, J. Amer. Chem. Soc, 59, 2372 (1937).

3) Furby, K. L. Wilkinson, J. Inorg. Nucl. Chem. 14, 124 (1960).

4) M. A. Greenbaum, R. E. Yates, J. Phys. Chem. 67, 1802 (1963).

5) M. V. Smirnov, Dokl. Akad. Nauk. SSSR. 127, 1066 (1959).

6) M. V. Smirnov, Zhur. Fiz. Khim. 32, (No. 9), 2165 (1958).

7) L. Brewer, Natl. Nucl. Sci. Ser. Div. IV, 19B, 76 (1953).
8) K. K. Kelley, Bull, U.S. Bur. Mines. No. 477 (1949).

9) A. Glassner, ANL-5750

10) D. C. Ginnings, J. Amer. Chem. Soc. 73, 1236 (1951).

11) K. K. Kelley, Bull, U.S. Bur. Mines. 476 (1949).

12) R. A. McDonald, Et al., J. Phys. Chem. 69, 3839 (1965).

13) W. H. Johnson, et al., J. Research of Natl. Bur. Standards. A. Phys. Chem. 65A, (No.1), (1961).

14) IU. K. Delimarskii, B. F. Markov, Electrochemistry of fused salts, 302, The Sigma Press (1961).

15) W. Biltz, et al., Z. anorg. allg. Chem. 133, 277 (1924).

16) P. Drossbach, Elektrochemie geschmolzener Salze p. 70 (1938).

17) IU. K. Delimarskii, et. al., Zhur. Fiz. Khim. 29, 1499 (1955).

18) R. E. Rundle, J. Chem. Phys. 20, 1, 132 (1952).

19) L. N. Ryabchikov, G. F. Tikhinskii, Fiz. Metal \& Metalloved A kad. Nauk. SSSR. 10, 635 (1960).

20) Eucken, Die Chemie, 55, 163 (1943).

21) J. O'M. Bockris, et al., J. Phys. Chem. 60, 1125 (1956).

22) S. A. Rice, Disc. Farad. Soc. 32, 181 (1961).

23) M. C. Bell, J. Flengas, J. Electrochem. Soc. 3, (No. 5), 575 (1964).

\title{
On the Cupric Oxalate Cell $(1)^{*}$ Studies on the Immersion Battery Using Sea Water as Electrolyte.V.
}

\author{
Yu AOKI and Masao HiroI \\ Chemical Laboratory, Kobe University of Mercantile Marine, \\ Fukae Honjo-cho, Higashinada-ku, Kobe
}

Received Sept. 20, 1967

Cupric oxalate - magnesium immersion type battery was assembled and open circuit voltage, discharge characteristics and coulombic efficiency were measured in order to examine the utility of the battery using cupric oxalate as cathode depolarizer.

The open circuit voltage of the $\mathrm{CuC}_{2} \mathrm{O}_{4}-\mathrm{Mg}$ cell was $1.71-1.79 \mathrm{~V}$ immediately after immersion and gradually decreased to stable voltage of $1.43 \mathrm{~V}$. When this battery was discharged at $20^{\circ} \mathrm{C}$ through $20 \mathrm{ohms}$ (average current density: $26 \mathrm{~mA} / \mathrm{cm}^{2}$ ), $61 \%$ of the theoretical capacity was delivered to a cut-off of $1.0 \mathrm{~V}$.

Though the cell has a disadvantage that the internal resistance increases gradually as discharge proceeds, this system can be used as single shot battery in emergency flares, air-sea rescue equipment and direction finding equipment etc.

* The original written in Japanese can be seen in Denki-Kagaku 35,493 (1967). 